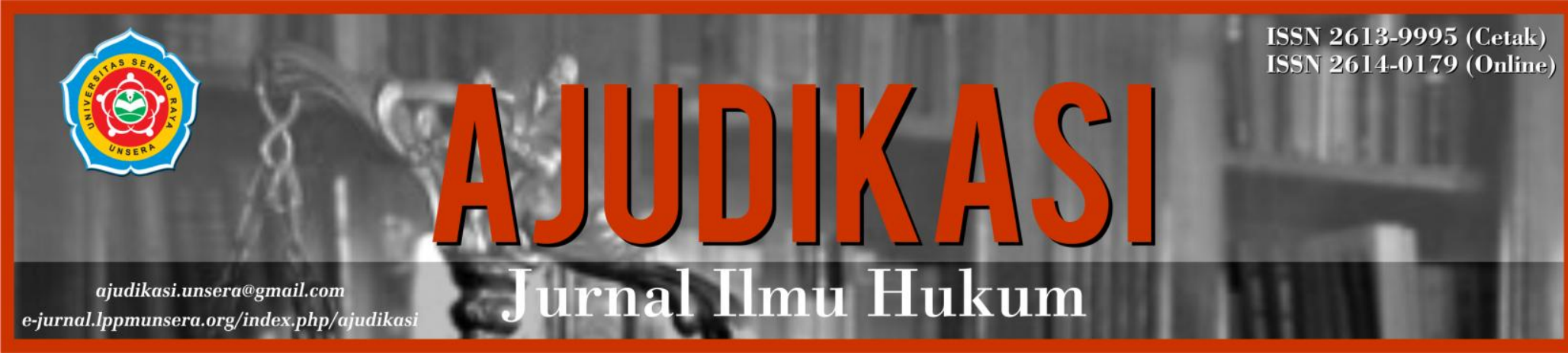

\title{
PERLINDUNGAN HUKUM TERHADAP KONSUMEN PENGGUNA TEKNOLOGI FINANSIAL BERBASIS PEER TO PEER LENDING SYARIAH DI INDONESIA
}

\author{
${ }^{1}$ Delfa Violina, ${ }^{2}$ Renny Supriyatni, ${ }^{3}$ Djanuardi \\ Fakultas Hukum, Universitas Padjadjaran, Bandung, Jawa Barat. \\ Correspondent email : violinadelfa @ gmail.com
}

$\begin{array}{lll}\mid \text { Article History } & : & \\ \mid \text { Submission } & : & \text { 30 April } 2021 \\ \mid \text { Last Revissions } & : & \text { 5 Juni } 2021 \\ \text { Accepted } & : & \text { 7 Juni 2021 } \\ \text { | Copyedits Approved } & : & \text { 9 Juni 2021 }\end{array}$

\begin{abstract}
Abstrack
Today's technological developments are increasingly developing, one of the sectors affected by this technological development is the economic sector. Peer to Peer Lending is a product of technology in the economic sector. Considering that Indonesia is a country with a majority Muslim population, making Peer to Peer Lending experience a change from conventional to sharia. Peer to peer lending sharia must follows sharia principles based on the rules established by the Otoritas Jasa Keuangan and Fatwa Majelis Ulama Indonesia. The convenience provided by Peer to Peer Lending Syariah has the possibility to all the risks that exist, making the government try to be able to protect all parties with existing regulations. This research will be using normative juridical methods, which connected with all the theories, concepts, documents, and regulation which related to peer to peer lending syariah. Therefore, this journal aims to understand positive legal provisions related to the implementation of Peer to Peer Lending sharia and legal protection and legal action that can be taken by consumers based on the regulation of Peer to Peer Lending.
\end{abstract}

Keywords: Technology; Financial; Peer to Peer Lending; Consumer; Syariah. 


\section{A. PENDAHULUAN}

Revolusi Industri pada dasarnya merupakan suatu perubahan yang memiliki sifat cepat dalam bidang ekonomi. segala revolusi yang berdampak pada sektor perekonomian hal tersebut memberikan inovasi-inovasi baru di bidang pendanaan dan pembiayaan. Sektor perekonomian di Indonesia pun terbagi menjadi tiga (3), yaitu pertama sektor perbankan, pasar modal, dan sektor industri keuangan non-bank. Berdasarkan data Bank Indonesia pada tahun 2019, kebutuhan pendanaan di Indonesia selama 1 (satu) tahun bisa mencapai angka Rp. 1.800.000.000.000 (satu triliyun delapan ratus miliyar rupiah), tetapi yang dapat dipenuhi atau dibantu oleh lembaga keuangan hanya sebesar Rp. 600.000.000.000 (enam ratus miliyar rupiah). Dengan demikian terdapat Rp. 1.200.000.000.000 (satu triliyun dua ratus miliyar rupiah) yang tidak dapat dibantu oleh lembaga keuangan, seperti bank maupun koperasi. Hal tersebut dikarenakan adanya beberapa persyaratan yang lebih kompleks dalam aturan bank maupun koperasi sehingga masyarakat yang tidak memenuhi persyaratan tidak dapat mendapatkan bantuan dana tersebut. Oleh karena itu, terbentuklah suatu model pemodalan dalam bentuk finansial teknologi sebagai solusi pendanaan. Jasa finansial teknologi pada dasarnya memberikan kemudahan dalam bertransaksi. Persyaratan yang lebih mudah atau fleksibel membuat financial teknologi menjadi lebih terkenal dari tahun ke tahun. Mekanisme dan skema yang lebih mudah dibandingkan pinjam meminjam melalui bank maupun lembaga lainnya.

Sektor perekonomian yang terkena dampak akan perkembangan teknologi, di mana dalam hal ni menggabungkan antara teknologi dengan sektor ekonomi. ${ }^{1}$ Penggabungan kedua hal tersebut sering disebut sebagai teknologi finansial. Berdasarkan Pasal 1 angka 1 Peraturan Bank Indonesia Nomor 19/12/PBI/2017 tentang Penyelenggaraan Teknologi Finansial (selanjut disebut sebagai PBI No 19/12/PBI/2017) bahwa teknologi finansial (selanjutnya disebut sebagai Fintech) merupakan pelaku usaha yang menggunakan teknologi dalam menghasilkan layanan, teknologi, produk, dan/atau model bisnis pada sistem keuangan di mana teknologi tersebut akan berdampak pada stabilitas moneter negara. Salah satu contoh dari hadirnya fintech antara lain adanya Peer to Peer Lending (selanjutnya disebut sebagai P2P Lending). Dasar hukum P2P Lending ini terdapat di dalam Peraturan Otoritas Jasa Keuangan Nomor 77/POJK.01/2016 tentang Layanan Pinjam Meminjam Uang Berbasis Teknologi informasi (selanjutnya disebut sebagai POJK No 77/POJK.01/2016). Menurut Pasal 1 angka 3 POJK No 77/POJK.01/2016 menyatakan bahwa P2P Lending merupakan penyelenggaraan layanan jasa keuangan yang bertujuan untuk mempertemukan pemberi pinjaman dengan penerima pinjaman dalam rangka melakukan suatu perjanjian pinjam meminjam dalam mata uang rupiah secara langsung melalui sistem elektronik dengan menggunakan jaringan internet.

\footnotetext{
1 M. Hadyan Yunhas Purba, "Penguatan Perlindungan Konsumen Dalam Industri Peer to Peer Lending Di Indonesia," Kanun Jurnal Ilmu Hukum 22, no. 3 (2020): 4.
} 
P2P Lending yang sejauh ini terkenal di dalam sistem keuangan konvensional, perlahan-lahan masuk ke dalam sistem keuangan syariah, mengingat negara Indonesia yang merupakan negara dengan mayoritas penduduk beragama Islam terbesar di Asia. Oleh sebab itu, terdapat potensi yang besar dalam pengembangan transaksi-transaksi keuangan modern yang berbasis syariah. Berdasarkan data yang dihimpun pada akhir tahun 2018 pemerintah telah mengeluarkan peraturan melalui Fatwa Dewan Syariah Nasional Majelis Ulama Indonesia Nomor 117/DSN-MUI/II/2018 Tentang Layanan Pembiayaan Berbasis Teknologi informasi Berdasarkan Prinsip Syariah (selanjutnya disebut dengan Fatwa DSN MUI No 117/DSN-MUI/II/2018). Segala kemudahan yang diberikan oleh P2P Lending baik konvensional maupun syariah tidak menutup kemungkinan akan segala resiko yang ada.

Perkembangan dunia digital memiliki potensi yang besar untuk timbul kejahatankejahatan digital. Kejahatan yang timbul seringkali merugikan konsumen yang menggunakan sistem digital tersebut. Semakin tinggi perkembangan teknologi di Indonesia, semakin tinggi pula permasalahan terkait perlindungan konsumen atas penggunaan teknologi yang sudah berkembang. ${ }^{2}$ Salah satu kasus yang ada di dalam P2P Lending syariah alah kasus Berkah Fintech Syariah. Dewi Anita Anugrahwati merupakan salah satu korban yang menyampaikan keluh kesahnya di website mediakonsumen. Dewi Anita menyatakan bahwa sistem operasional yang buruk yang diselenggarakan oleh Berkah Fintech Syariah, berimplikasi pada kinerja yang buruk sehingga banyak korban dari penyelenggaraan fintech syariah dari nasabah atau konsumen pengguna Berkah Fintech Syariah. ${ }^{3}$ Dewi Anita meminjam uang sebesar 1.090.080 melalui Berkah Fintech Syariah dengan tipe murabahah serta jatuh tempo pembayarannya pada tanggal 17 Desember 2020. Dewi Anita dalam hal ni telah membayar hutangnya pada tanggal 16 Desember 2020. Namun, pembayaran yang dilakukan oleh Dewi Anita tidak tercatat di dalam sistem operasional milik Berkah Fintech Syariah sehingga berakibat pada pemberlakuan denda karena dianggap telat melakukan pembayaran. Oleh karena itu, Dewi Anita merasa telah dirugikan secara materiil. Korban lainnya adalah saudara Bayu Aji yang telah membayar tagihan satu hari sebelum jatuh tempo, namun dikarenakan ada terdapat masalah dalam sistem operasional sehingga Bayu Aji dianggap belum membayar tagihan serta diminta untuk membayar denda. ${ }^{4}$

Berdasarkan kasus yang diselenggarakan oleh Berkah Fintech Syariah (BFS), memperlihatkan bahwa tidak ada penerapan ketentuan atau prinsip syariah. Untuk melindungi seluruh konsumen atas pelaksanaan P2P Lending sudah menjadi tanggung jawab dari Otoritas Jasa Keuangan (OJK). OJK dalam hal ini sudah mengupayakan untuk dapat memenuhi atau melindungi seluruh pihak dari kegiatan-kegiatan yang dapat merugikan,

\footnotetext{
2 Johannes Gunawan, "Fungsi Lembaga Pertanggungjawaban Produk Dalam Upaya Perlindungan Konsumen Di Indonesia" (2003).

${ }^{3}$ Dewi Anita, "Sistem Penagihan Pinjol Berkah Fintek Syariah Bermasalah,” Mediakonsumen, 2020.

${ }^{4}$ Ibid.
} 
salahnya satu yang dapat menjadi payung hukum dalam melindungi konsumen melalui POJK Nomor 1/POJK.07/2013 tentang Perlindungan Konsumen Sektor Jasa Keuangan, Undang-Undang Informasi dan Transaksi Elektronik (ITE), Kitab Undang-Undang Hukum Pidana (KUHP), maupun Kitab Undang-Undang Hukum Perdata (KUHPer). Upaya memberikan perlindungan hukum kepada pengguna Fintech berbasis P2P Lending syariah dilakukan dengan mengubah sistem keuangan konvensional seperti mulai dari urusan perbankan, peminjaman, pembayaran, manajemen aset, hingga tahapan regulasi. Oleh karena itu, penelitian ini akan mengkaji bagaimana pengaturan layanan teknologi finansial berbasis P2P lending syariah dikaitkan dengan tindakan pelanggaran yang dilakukan oleh penyelenggara P2P lending syariah serta implementasi perlindungan hukum terhadap konsumen dalam praktek penyelenggaraan teknologi finansial berbasis P2P lending syariah.

Berkaitan dengan penjelasan pada latar belakang, maka penulis akan membahas beberapa pokok permasalahan, yaitu mengenai pengaturan layanan teknologi finansial berbasis $\mathrm{P} 2 \mathrm{P}$ lending syariah dikaitkan dengan tindakan pelanggaran yang dilakukan oleh penyelenggara $\mathrm{P} 2 \mathrm{P}$ lending syariah ditinjau dari regulasi hukum perbankan syariah dan implementasi perlindungan hukum terhadap konsumen dalam praktek penyelenggaraan teknologi finansial berbasis P2P lending syariah ditinjau dari regulasi hukum perbankan syariah.

\section{B. METODE PENELITIAN}

Penelitian ini menggunakan metode pendekatan yuridis normatif, yaitu pendekatan penelitian hukum yang dilakukan dengan meneliti bahan kepustakaan atau data sekunder sebagai bahan penelitian yang utama. Berkaitan dengan metode pendekatan ini, penelitian akan dikonsepkan sebagai apa yang tertulis dalam peraturan perundang-undangan (law in books) atau hukum yang dikonsepkan sebagai kaidah atau norma yang menjadi patokan berperilaku manusia yang dianggap pantas. ${ }^{5}$ Penelitian ini juga bertujuan untuk mengetahui permasalahan apa saja yang ada di lapangan. Permasalahan yang ada di dalam lapangan akan dihubungkan dengan teori-teori, konsep-konsep, dokumen, serta peraturan perundangundangan yang berhubungan dengan penelitian ini. ${ }^{6}$ Permasalahan yang telah dikaji dengan bahan kepustakaan baik primer maupun sekunder akan mendapatkan atau menemui permasalahan-permasalahan dalam pelaksanaan atau mekanisme P2P Lending Syariah di Indonesia serta tindakan hukum yang dapat dilakukan oleh konsumen untuk melindungi hak-haknya berdasarkan ketentuan Peer to Peer Lending Syariah di Indonesia.

\footnotetext{
${ }^{5}$ Peter Mahmud Marzuki, Penelitian Hukum (Jakarta: Kencana Prenada Media Group, 2005).

${ }^{6}$ Soerjono Soekanto dan Sri Mamudji, Penelitian Hukum Normatif: Suatu Tinjauan Singkat (Jakarta: PT Raja Grafindo Persada, 2003).
} 


\section{HASIL DAN PEMBAHASAN}

\section{Pengaturan Layanan Teknologi Finansial Berbasis P2P Lending Syariah Dikaitkan Dengan Tindakan Pelanggaran Yang Dilakukan Oleh Penyelenggara P2P Lending Syariah}

Perkembangan teknologi informasi yang semakin pesat serta masyarakat yang mulai beralih pada penggunaan teknologi dalam berbagai aspek kehidupan berdampak pada proses layanan yang perlu mendukung dan memudahkan pelayanan konsumen. Salah satu aspek yang turut serta dalam perkembangan teknologi informasi saat ini adalah dunia perbankan. Dimana pelayanan perbankan harus menyesuaikan dengan dinamika masyarakat yang semakin dimanjakan dengan adanya teknologi informasi, termasuk teknologi finansial. Pelayanan finansial yang telah memasuki era teknologi informasi memberikan kemudahan akan tetapi perlu mendapatkan perlindungan agar tidak mengakibatkan persoalan di masa yang akan datang. Oleh karena itu, layanan teknologi financial perlu mendapatkan pengaturan sehingga memberikan rasa aman bagi para pelaku digitalisasi pelayanan oleh konsumen yang salah satunya berkaitan dengan pelayanan peer to peer (P2P) lending syariah.

a. Pengaturan Layanan P2P Lending Syariah

Dalam era perkembangan teknologi dan digitalisasi, kebutuhan rakyat akan aktivitas pada sektor jasa keuangan yang mudah, cepat dan fleksibel pun meningkat. Sehingga hal ni mendorong para pelaku jasa keuangan buat terus melakukan penemuan akibat perubahan transaksi secara tradisional kepada bentuk digital. P2P Lending merupakan salah satu inovasi dari masuknya teknologi dalam dunia ekonomi. P2P Lending berdasarkan Pasal 1 angka 3 POJK nomor 7/POJK.01/2016 menjelaskan bahwa:

"Layanan Pinjam Meminjam Uang Berbasis Teknologi informasi adalah penyelenggaraan layanan jasa keuangan untuk mempertemukan pemberi pinjaman dengan penerima pinjaman dalam rangka melakukan perjanjian pinjam meminjam dalam mata uang rupiah secara langsung melalui sistem elektronik dengan menggunakan jaringan internet"

Maka dari itu, P2P Lending dapat juga dikatakan sebagai pinjam meminjam menggunakan teknologi informasi umumnya memfasilitasi pihak yang memerlukan dana pinjaman dengan para pihak yang mau berinvestasi dengan dengan metode memberikan pinjaman. P2P Lending yang sepanjang ni dikenal di dalam sistem keuangan konvensional, lambat laun masuk ke dalam sistem keuangan Syariah, mengingat negara Indonesia yang merupakan negara dengan penduduk mayoritas beragama Islam terbesar di Asia. ${ }^{7}$ P2P Lending Syariah merupakan produk dari fintech syariah. Menurut Mukhlisin fintech syariah merupakan gabungan atau

\footnotetext{
7 Raden Ani Eko Wahyuni, "Perkembangan Ekonomi Islam Di Indonesia Melalui Penyelenggaraan Fintech Syariah". Mahkamah: Jurnal Kajian Hukum Islam 4, no. 2 (2019): 185
} 
inovasi yang terdapat dalam bidang keuangan serta teknologi yang mempermudah kegiatan transaksi serta investasi bersumber pada prinsip-prinsip syariah. ${ }^{8} \mathrm{P} 2 \mathrm{P}$ Lending Syariah bisa dimaksudkan sebagai kegiatan pemberian pinjaman dana kepada orang atau badan usaha serta pula kebalikannya dalam mengajukan pinjaman buat kepentingan individu ataupun badan usaha dengan didasari dengan nilai serta prinsip syariah. Prinsip-prinsip syariah yang diatur dalam Fatwa DSN MUI No. 117/DSN-MUI/II/2018 Tentang Layanan Pembiayaan Berbasis Teknologi informasi Berdasarkan Prinsip Syariah pada Ketentuan Umum, terdapat 6 akad yakni:

1) Al-bai. Akad ba'i atau akad jual beli merupakan akad antara pembeli dan penjual yang menyebabkan berpindahnya kepemilikan obyek yang dipertukarkan (barang serta harga)

2) Ijarah. Akad ijarah merupakan akad kegiatan untuk melakukan perubahan atas hak guna mengenai sesuatu benda ataupun jasa dalam jangka periode tertentu dengan pembayaran ujrah ataupun upah.

3) Mudharabah. Akad Mudharabah merupakan kegiatan yang dilandasi saling kerjasama antara salah satu pihak sebagai pemilik modal yang memiliki cukup uang untuk membantu pihak lain (pengelola) dalam menyediakan modal, dalam hal ini keuntungan yang diperoleh oleh para pihak berdasarkan kesesuaian yang telah disepakati oleh para pihak dan untuk kerugiannya akan ditanggung oleh pihak yang membantu dalam penyediaan modal.

4) Musyarakah. Akad Musyarakah merupakan kegiatan yang dilandasi kerjasama antara dua pihak ataupun lebih teruntuk suatu tindakan tertentu dalam hal ini para pihak memberikan bantuan dan modal usaha berdasarkan persyaratan bahwa keuntungan akan dibagi setara dengan nisbah yang telah disepakati atau secara rasio yang adil bagi para pihak, namun kerugian akan ditanggung oleh para pihak.

5) Wakalah bi al ujrah. Akad wakalah merupakan kegiatan dalam penyerahan kuasa oleh pemberi kuasa (muwakkil) kepada penerima kuasa (wakil) dalam hal melaksanakan beberapa tindakan hukum yang boleh diwakilkan. Akad wakalah bi al-ujrah merupakan akad wakalah yang disertai dengan imbalan berupa ujrah.

6) Qardh. Akad Qardh merupakan akad pinjaman oleh pemberi pinjaman dengan persyaratan bahwa penerima pinjaman harus mengembalikan dana yang diterimanya sesuai dengan waktu dan cara yang disepakati

\footnotetext{
${ }^{8}$ Dodi Yarli, "Analisis Akad Tijarah Pada Transaksi Fintech Syariah Dengan Pendekatan Maqhasid," Jurnal YUDISI 9, no. 2 (2018): 2. 
Selain prinsip tersebut, P2P lending syariah inipun dalam pelaksanaannya wajib menghindari adanya riba, gharar, maysir, tadlis, dan dharar. Pertama, riba berarti akad untuk satu ganti khusus tanpa diketahui perbandingannya dalam penilaian syariat ketika berakad atau bersama dengan mengakhirkan kedua ganti atau salah satunya. ${ }^{9}$ Kedua, gharar adalah jual beli barang yang belum ada ( $m a$ 'dum), jual barang yang tidak jelas $(M a j h u)$, dan jual beli barang yang tidak mampu diserahterimakan. ${ }^{10}$ Ketiga, maysir merupakan tindakan yang bersifat tidak pasti di mana tindakan ini berdasarkan spekulatif ataupun untung-untungan. ${ }^{11}$ Keempat, tadlis adalah tindakan yang dilakukan oleh penjual untuk mengelabui si pembeli dengan cara menyembunyikan kecacatan objek yang akan dijual oleh si penjual kepada pembeli. Terakhir, dharar adalah segala kegiatan yang dapat membawa kerugian kepada pihak lain.

b. Model layanan pembiayaan berbasis teknologi informasi

Model pelayanan pembiayaan berbasis teknologi sebagaimana dituangkan dalam Bab 5 dalam aturan Fatwa DSN-MUI menjelaskan mengenai model layanan pembiayaan berbasis teknologi informasi berdasarkan prinsip syariah yang bisa dilakukan oleh penyelenggara antara lain:

1) Pembiayaan anjak piutang (factoring)

Anjak piutang syariah sudah diatur sendiri dalam Fatwa DSN-MUI Nomor 67/DSN-MUI/III/2008. Pembiayaan anjak piutang merupakan suatu kegiatan yang menangani mengenai penagihan hutang melalui bukti tagihan (invoice), dalam hal ini diperbolehkan apabila tanpa adanya talangan (qardh) dari pelaku usaha yang memiliki tagihan kepada pihak ketiga. Dalam layanan ini dasar terjadinya kegiatan pembiayaan anjak piutang dikarenakan terdapat hubungan hukum akibat kegiatan hukum utang piutang menggunakan bukti tagihan melalui calon penerima pembiayaan kepada pihak ketiga. Penagihan ini menggunakan akad wakalah bi al-ujrah.

Pelaksanaan pembiayaan anjak piutang ini dilakukan oleh penyelenggara sebagai wakil dari pemberi pembiayaan untuk melakukan penagihan hutang kepada penerima pembiayaan. Lebih lanjut, penyelenggara juga dapat memberikan talangan dana dengan akad qardh kepada penerima pembiayaan jasa. Penyelenggara melakukan penagihan kepada pihak ketiga (payor) atas piutang penerima pembiayaan. Penyelenggara memiliki hak untuk

\footnotetext{
9 Sutan Remy Sjahdeini, Perbankan Syariah Produk-Produk Dan Aspek-Aspek Hukumnya (Jakarta: Kencana Prenamedia Group, 2014).

10 Ash-Shawi dan Muhammad Shalah Muhammad, Problematika Investasi Pada Bank Slam Solusi Ekonomi (Jakarta: Migunani, 2008).

${ }^{11}$ Azzam Abdul dan Aziz Muhammad, Fiqh Muamalat System Transaksi Dalam Islam (Jakarta: AMZAH, 2010).
} 
mendapatkan ujrah dari penerima pembiayaan seta selanjutnya penyelenggara wajib memberikan ujrah dan qard (jika ada) kepada pemberi pembiayaan.

2) Pembiayaan pengadaan barang pesanan pihak ketiga

Pelaku usaha memiliki hak untuk mendapatkan pembiayaan atas kegiatan yang telah dilakukan oleh pelaku usaha dalam menjalankan pesanan atau surat perintah kerja pengadaan barang dari pihak ketiga. Terdapat hubungan hukum akibat adanya kontrak atau perjanjian pengadaan barang antara pihak ketiga dan calon penerima pembiayaan, hubungan hukum itu merupakan dasar dari pembiayaan. Pelaksanaan dari pembiayaan pengadaan barang pesanan pihak ketiga ini dimulai dari calon penerima pembiayaan mengutarakan keinginannya dalam pembiayaan pengadaan barang kepada penyelenggara dari pihak ketiga. Selanjutnya, penyelenggara akan menjalankan penawaran kepada calon pemberi pembiayaan untuk membiayai pengadaan barang tersebut. Dalam melakukan pembiayaan dengan penerima pembiayaan, penyelenggara menggunakan akad jual beli (akad murabahah), mudharabah, atau musyarakah. Lebih lanjut, penerima pembiayaan wajib untuk melakukan pembayaran pokok dan imbal hasil kepada penyelenggara sesuai dengan kesepakatan dalam akad, selanjutnya penyelenggara akan menyerahkan imbal hasil serta pokok kepada pemberi pembiayaan.

3) Pembiayaan pengadaan barang untuk pelaku usaha yang berjualan secara online

pembiayaan yang diberikan kepada pelaku usaha yang melakukan transaksi jual beli online pada penyedia layanan perdagangan berbasis teknologi yang telah menjalin kerjasama dengan penyelenggara. Pembiayaan ini menggunakan akad wakalah bi al-ujrah apabila calon pemberi pembiayaan menyetujui penawaran yang dilakukan oleh penyelenggara. Dalam melakukan Pembiayaan pengadaan barang untuk pelaku usaha yang berjualan secara online, penyelenggara menggunakan akad jual beli (akad murabahah), musyarakah, atau mudharabah. Lebih lanjut, penerima pembiayaan wajib untuk melakukan pembayaran pokok dan imbal hasil kepada penyelenggara sesuai dengan kesepakatan dalam akad, selanjutnya penyelenggara akad menyerahkan pokok dan imbal hasil kepada pemberi pembiayaan.

4) Pembiayaan pengadaan barang untuk pelaku usaha yang berjualan secara online dengan pembayaran melalui penyelenggara payment gateway.

Kegiatan yang dilakukan ialah memberikan pembiayaan kepada pelaku usaha yang aktif berjualan secara online yang dikelola sendiri melalui saluran distribusi, di mana pelunasan akan dilakukan lewat penyedia jasa otoritas pembayaran secara online yang bekerjasama dengan pihak penyelenggara. 
Pelaksanaan Pembiayaan pengadaan barang untuk pelaku usaha yang berjualan secara online dengan pembayaran melalui penyelenggara payment gateway, dimulai dari penjual online akan meminta atau mengajukan pembiayaan kepada penyelenggara di mana pembiayaan itu akan digunakan untuk pengadaan barang. Selanjutnya penyelenggara akan meminta kepada pemberi pembiayaan untuk membiayai pengadaan barang. Apabila ketiga pihak sudah saling setuju maka penyelenggara menggunakan akan jual beli (akad murabahah), musyarakah, atau mudharabah. Lebih lanjut, penerima pembiayaan wajib untuk melakukan pembayaran pokok dan imbal hasil kepada penyelenggara sesuai dengan kesepakatan dalam akad, selanjutnya penyelenggara akan menyerakan pokok dan imbal hasil kepada pemberi pembiayaan.

5) Pembiayaan untuk Pegawai (employee)

Memberikan pembiayaan kepada pegawai dengan skema kerjasama potong gaji melalui instansi pemberi kerja. Salah satu syarat pegawai yang dapat diberikan bantuan ialah pegawai yang mendapatkan gaji tetap dari institusi yang bekerjasama dengan penyelenggara. Penerima pembiayaan membayar pokok dan imbal hasil kepada penyelenggara dengan cara pemotongan gaji dan pemberi pembiayaan memiliki hak untuk mendapatkan pokok dan imbal hasil dari penyelenggara.

6) Pembiayaan berbasis komunitas (community based)

Layanan yang diberikan kepada anggota komunitas yang membutuhkan pembiayaan dengan menggunakan metode pelunasan yang dikoordinasikan bersama pengurus komunitas. Pelaku usaha yang dapat diberikan bantuan pembiayaan alah pelaku usaha yang tergabung dalam komunitas usaha tertentu yang bekerja sama dengan penyelenggara. Apabila seluruh pihak telah saling setuju maka, penyelenggara akan menggunakan akad jual beli (akad murabahah), musyarakah, atau mudharabah. Lebih lanjut, penerima pembiayaan wajib untuk melakukan pembayaran pokok dan imbal hasil kepada penyelenggara sesuai dengan kesepakatan dalam akad, selanjutnya penyelenggara akan menyerahkan pokok dan imbal hasil kepada pemberi pembiayaan.

\section{c. Praktik Peer to Peer Lending di Indonesia}

Perkembangan praktik P2P lending konvensional sudah masuk ke dalam Indonesia dimulai dari tahun 2015. Namun perkembangannya untuk sampai ke ranah P2P Lending syariah dapat dikatakan cukup lambat. Tahun 2018 adalah tahun pertama munculnya P2P Lending Syariah di Indonesia, akan tetapi baru mulai didaftarkan dalam bentuk P2P Lending Syariah pada OJK dimulai tahun 2019. 
Proses perkembangan yang memakan waktu cukup lambat dibandingkan perkembangan P2P Lending konvensional di Indonesia. Berdasarkan data perusahaan Fintech Peer to peer lending di Indonesia yang memiliki izin dan sudah terdaftar di OJK berjumlah 149 Fintech baik yang bergerak di jenis usaha konvensional maupun syariah. Peer to peer lending syariah yang terdaftar dan memiliki izin oleh OJK antara lainnya. $^{12}$

Tabel 1. Nama Penyelenggara Fintech P2P Lending Syariah yang Terdaftar di OJK

\begin{tabular}{|l|l|l|l|}
\hline No & $\begin{array}{l}\text { Nama } \\
\text { Platform }\end{array}$ & Nama Perusahaan & $\begin{array}{l}\text { Surat } \\
\text { Berizin/ Terdaftar }\end{array}$ \\
\hline 1 & Investree & $\begin{array}{l}\text { PT Investree } \\
\text { Radika Jaya }\end{array}$ & KEP-45/D.05/2019 \\
\hline 2 & Ammana.id & $\begin{array}{l}\text { PT Ammana Fintek } \\
\text { Syariah }\end{array}$ & $\begin{array}{l}\text { KEP } \\
123 / D .05 / 2019\end{array}$ \\
\hline 3 & ALAMI & $\begin{array}{l}\text { PT Alami Finteck } \\
\text { Sharia }\end{array}$ & KEP -21/D.05/2020 \\
\hline 4 & $\begin{array}{l}\text { DANA } \\
\text { SYARIAH }\end{array}$ & $\begin{array}{l}\text { PT Dana Syaria } \\
\text { Indonesia }\end{array}$ & $\begin{array}{l}\text { S- } \\
384 / N B .213 / 2018\end{array}$ \\
\hline 5 & $\begin{array}{l}\text { Duha } \\
\text { SYARIAH }\end{array}$ & $\begin{array}{l}\text { PT Duha Madani } \\
\text { Syariah }\end{array}$ & $\begin{array}{l}\text { S- } \\
292 / N B .213 / 2019\end{array}$ \\
\hline 6 & Qazwa & $\begin{array}{l}\text { PT Qazwa Mitra } \\
\text { Hasanah }\end{array}$ & $\begin{array}{l}\text { S- } \\
440 / N B .213 / 2019\end{array}$ \\
\hline 7 & bsalam & $\begin{array}{l}\text { PT Maslahat } \\
\text { Indonesia Mandiri }\end{array}$ & $\begin{array}{l}\text { S- } \\
441 / N B .213 / 2019\end{array}$ \\
\hline 8 & ETHIS & $\begin{array}{l}\text { PT Ethis Fintek } \\
\text { Indonesia }\end{array}$ & $\begin{array}{l}\text { S- } \\
608 / N B .213 / 2019\end{array}$ \\
\hline 9 & $\begin{array}{l}\text { KAPITALBO } \\
\text { OST KT Kapital Boost }\end{array}$ & $\begin{array}{l}\text { S- } \\
\text { Indonesia }\end{array}$ & $609 / \mathrm{NB} .213 / 2019$ \\
\hline 10 & $\begin{array}{l}\text { PAPITUPI } \\
\text { Syariah }\end{array}$ & $\begin{array}{l}\text { PT Piranti Alphabet } \\
\text { Perkasa }\end{array}$ & $\begin{array}{l}\text { S- } \\
612 / N B .213 / 2019\end{array}$ \\
\hline 11 & $\begin{array}{l}\text { Finteck } \\
\text { Syariah }\end{array}$ & $\begin{array}{l}\text { PT Berkah Finteck } \\
\text { Syariah }\end{array}$ & $\begin{array}{l}\text { S- } \\
600 / N B .213 / 2019\end{array}$ \\
\hline
\end{tabular}

Dari 149 P2P Lending yang terdaftar di OJK hanya ada 11 P2P Lending Syariah di Indonesia. Salah satu faktor yang menjadi penghambat dari perkembangan P2P Lending syariah ini adalah kurangnya literasi yang memadai dalam hal ekonomi syariah. Serta regulasinya yang belum cukup ketat banyak yang belum berani untuk menggunakan produk P2P Lending syariah ini sendiri, mengingat aturan yang ada saat ini ialah hanya ada FATWA DSN MUI Nomor 117/DSN-MUI/II/2018 tentang Layanan Pembiayaan Berbasis Teknologi Berdasarkan Prinsip Syariah di mana pada dasarnya aturan ini tidak memiliki

\footnotetext{
${ }^{12}$ Web Resmi OJK, “Penyelenggara Fintech Terdaftar Dan Berizin Di OJK per Desember 2020,” n.d.
} 
kekuatan mengikat serta POJK Nomor 77/POJK.01/2016 tentang Layanan Pinjam Meminjam Uang Berbasis Teknologi informasi yang di mana banyak ketentuan-ketentuan syariah yang tidak diatur dalam aturan tersebut.

Transparansi P2P Lending Syariah yang terdaftar di OJK dari sistem keuangannya pun jelas sehingga dapat terpantau oleh OJK. Memang pada dasarnya ke-11 P2P Lending syariah tersebut sudah melaksanakan akad-akad yang ada di FATWA DSN MUI Nomor : 117/DSN-MUI/II/2018, namun tidak menutup kemungkinan tidak terjadi kesalahan. Sering kali P2P Lending Syariah menuntut pembayaran kepada konsumen tidak menggunakan prinsip-prinsip atau nilai-nilai yang didasarkan pada syariah Islam, di mana tata cara penagihan memang tidak diatur baik dalam hukum positif Indonesia maupun aturan lainnya. Hal tersebut sering kali menjadi problematika dari P2P Lending Syariah di Indonesia. Tidak hanya itu saja, memang P2P Lending Syariah tidak mengenal kata bunga, namun mereka tetap mengenal kata denda apabila konsumen telat membayar hutangnya, dalam hal ini denda sering kali digunakan untuk mengganti bunga dimana besaran persentasenya pun cukup tinggi. Berdasarkan Data yang dimiliki oleh OJK dari Juli 2018 hingga Desember 2020 sudah tercatat 35.250 perusahaan P2P Lending baik konvensional maupun syariah yang ilegal. Dalam praktiknya banyak sekali konsumen yang dirugikan dengan adanya P2P Lending ilegal. Oleh karena itu, OJK selalu memberikan penyuluhan kepada masyarakat terkait $\mathrm{P} 2 \mathrm{P}$ Lending ilegal dan membuat website di mana masyarakat dapat melihat perusahaan mana saja yang tidak memiliki lisensi dari OJK. ${ }^{13}$

\section{Implementasi Perlindungan Hukum Terhadap Konsumen Dalam Praktek Penyelenggaraan Teknologi Finansial Berbasis P2P Lending Syariah}

Kehadiran teknologi finansial tentunya membawa kemudahan bagi masyarakat dalam memenuhi kebutuhan sehari-harinya. P2P Lending salah satu produk dari keberhasilan financial technology. Dewasa ini P2P Lending dianggap sebagai metode investasi baru yang menguntungkan bagi pemberi pinjaman maupun penerima pinjaman. Sama seperti investasi lainnya, setiap kelebihan pasti akan dibarengi dengan adanya kekurangan, begitupula P2P Lending. Kekurangan-kekurangan tersebut sudah menjadi kewajiban pemerintah untuk membentuk suatu regulasi yang dapat mengurangi atau melindungi setiap pihak yang dirugikan akibat kekurangan dari P2P Lending itu sendiri. Oleh karena itu, pentingnya suatu regulasi yang mengatur dan memberikan perlindungan hukum bagi para pelaku praktik teknologi finansial.

\footnotetext{
13 Dita Tania dan Sri Bakti Yunari, "Perlindungan Hukum Terhadap Konsumen Financial Technology Yang Berbasis Peer to Peer Lending Di Indonesia,” Jurnal Hukum Adigama 3, no. 1 (2020): 15.
} 
Perlindungan hukum dimaksudkan sebagai suatu bentuk perlindungan terhadap hak setiap orang yang didasarkan pada hukum atau perundang-undangan. ${ }^{14}$ Dengan demikian penyelenggaraan teknologi financial melalui peer to peer lending memperoleh jaminan hak bagi para pelaku baik konsumen maupun pihak penyelenggara. Dalam hal P2P lending syariah maka diperlukan suatu regulasi tertentu yang mengatur secara khusus praktik penyelenggaraan berbasis P2P lending syariah. Regulasi merupakan suatu instrumen penting dalam rangka memberikan pelayanan dan jaminan bagi masyarakat yang memberikan aturan secara substantif dalam memecahkan masalah-masalah yang ada ditengah-tengah masyarakat. ${ }^{15}$

Penyelenggaraan P2P Lending syariah yang baru dikenal tahun 2017 memiliki beberapa keresahan, dikarenakan P2P Lending syariah saat ini hanya berpatokan kepada aturan POJK Nomor 77/POJK.01/2016 tentang Layanan Pinjam Meminjam Uang Berbasis Teknologi informasi (selanjutnya disebut POJK Nomor 77/POJK.01/2016). Tentu aturan ini menimbulkan keresahan dikarenakan POJK Nomor 77/POJK.01/2016 merupakan aturan secara general yang mengatur mengenai fintech konvensional. Sementara itu, fintech syariah dan fintech konvensional memiliki sisi substansi yang berbeda. P2P Lending syariah pun tidak mengenal kata pinjam meminjam, yang dikenal di P2P Lending syariah alah kata pembiayaan. Tidak hanya kata atau bahasa yang berbeda, di P2P Lending pun tidak mengenal kata bunga. Tentu ini berbeda dengan P2P Lending konvensional yang di mana di dalam aturan POJK Nomor 77/POJK.01/2016 mewajibkan adanya suku bunga pinjaman. ${ }^{16}$

Sejauh ini P2P Lending syariah tunduk pada aturan POJK Nomor 77/POJK.01/2016 dan Fatwa DSN-MUI Nomor 117/DSN-MUI/II/2018 tentang Layanan Pembiayaan Berbasis Teknologi Berdasarkan Prinsip Syariah (selanjutnya disebut dengan Fatwa DSN-MUI No 117/DSN-MUI/II/2018). Fatwa DSN-MUI No. 117/DSNMUI/II/2018 ini pada dasarnya tidak termasuk di dalam peraturan perundang-undangan, sehingga tidak punya kekuatan mengikat untuk diikuti. ${ }^{17}$ Lebih lanjut, Fatwa MUI ini baru dapat dijadikan norma yang mengikat hukum ketika sudah dirumuskan dalam proses legislasi oleh pemerintah untuk dijadikan hukum nasional atau hukum positif. ${ }^{18}$ Tidak hanya itu, di dalam POJK Nomor 77/POJK.01/2016 dan Fatwa DSN-MUI No 117/DSN-

\footnotetext{
${ }^{14}$ Fuqoha Fuqoha, Indrianti Azhar Firdausi, and Arga Eka Sanjaya, "Perlindungan Hukum Terhadap Intervensi Pemberitaan Dalam Kerangka Kemerdekaan Pers Nasional,” Ajudikasi : Jurnal Ilmu Hukum 3, no. 1 (2019): 75, https://doi.org/10.30656/ajudikasi.v3i1.1436.

${ }^{15}$ Rokilah Rokilah, "The Role of the Regulations in Indonesia State System," Ajudikasi : Jurnal Ilmu Hukum 4, no. 1 (2020): 29-38, https://doi.org/10.30656/ajudikasi.v4i1.2216.

${ }^{16}$ Heri Suhendra, Ayon Diniyanto, "Pengawasan Dan Regulasi Terhadap Financial Technology Lending Syariah", El-Iqtishady 2 No. 2 (2020): 15

${ }^{17}$ Rahmatullah dan Nurhasanah dan Indra, "The Legal Protection of Sharia Financial Technology in Indonesia (Analysis of Regulation, Structure and Law Enforcement)," International Journal of Advanced Science and Technology 29, no. 3 (2020): 3089.

${ }^{18}$ Sovia Hasanah, "Kedudukan Fatwa MUI Dalam Hukum Nasional," hukumonline, 2021.
} 
MUI/II/2018 tidak ada sanksi yang mengikat apabila ada P2P Lending syariah yang tidak mengikuti ketentuan syariah yang telah diatur oleh Majelis Ulama Indonesia.

Dengan segala problematika yang ada sulit untuk memberikan perlindungan hukum kepada pihak yang dirugikan dalam pelaksanaan P2P Lending syariah. Melihat contoh kasus yang sudah dipaparkan di dalam poin pendahuluan di atas, yaitu kasus Dewi Anita dan Bayu Aji merupakan beberapa korban dari oknum P2P Lending Syariah BFS. Sistem operasional yang buruk dan sistem penagihan yang tidak sesuai dengan ketentuan syariah membuat Dewi Anita dan Bayu Aji mengalami kerugian baik kerugian material maupun materil. Dewi Anita dan Bayu Aji sama-sama telah membayar pinjaman yang mereka pinjam 2 (dua) hari sebelum tanggal jatuh tempo, namun pembayaran tersebut tidak tercatat di dalam sistem BFS, sehingga Dewi Anita dan Bayu Aji dianggap belum membayar pinjaman yang mereka pinjam dan dikenai denda akibat keterlambatan bayar. Dewi Anita dan Bayu Aji sudah mengirimkan bukti pembayaran kepada pihak BFS, namun belum mendapatkan respon dari pihak BFS. Akibat dari keterlambatan membayar, Dewi Anita dan Bayu Aji dikenakan sanksi untuk membayar tagihan/denda.

Berdasarkan pada kasus di atas terlihat terdapat kesalahan dari sistem operasional teknologi milik BFS sehingga tidak tercatat pembayaran yang dilakukan oleh Dewi Anita dan Bayu Aji. Berdasarkan Pasal 25 ayat (3) POJK Nomor 77/POJK.01/2016 menyatakan bahwa penyelenggara dalam hal ini BFS wajib memenuhi standar minimum sistem teknologi informasi, pengelolaan, pengamanan, dan ketahanan atas semua gangguan dan kegagalan sistem kelola teknologi informasi. Dalam Pasal 28 POJK Nomor 77/POJK.01/2016 juga menyatakan bahwa penyelenggara wajib memiliki sistem pencegahan dan penanggulangan terhadap ancaman yang di mana ancaman atau serangan tersebut dapat menimbulkan gangguan, kegagalan ataupun kerugian. Dalam hal ini Dewi Anita dan Bayu Aji mengalami kerugian atas kelalaian sistem operasional milik BFS.

Berdasarkan pasal 47 ayat (1) POJK Nomor 77/POJK.01/2016 seluruh pelanggaran dan kewajiban dan larangan yang diatur dalam aturan POJK Nomor 77/POJK.01/2016 dapat dikenakan sanksi administrasi berupa peringatan tertulis, denda, pembatasan kegiatan usaha, dan pencabutan usaha. Keempat sanksi ini tidak memiliki hierarki, di mana keempatnya ini dapat dikenakan atau diberikan secara tersendiri ataupun bersama-sama. ${ }^{19}$ BFS yang merupakan P2P Lending syariah yang pengawasannya ada di bawah Otoritas Jasa Keuangan, maka dalam melindungi konsumennya akan mengacu kepada POJK Nomor 1/POJK.07/2013 tentang Perlindungan Konsumen Sektor Jasa Keuangan (selanjutnya akan disebut POJK No 1/POJK.07/2013). Menurut Pasal 1 POJK No 1/POJK.07/2013 menyatakan bahwa perlindungan konsumen adalah perlindungan yang diberikan oleh pemerintah teruntuk

\footnotetext{
1947 ayat (1) POJK Nomor 77/POJK.01/2016 tentang Layanan Pinjam Meminjam Uang Berbasis Teknologi informasi
} 
seluruh konsumen yang menggunakan atau memanfaatkan pelayanan yang tersedia di lembaga jasa keuangan. ${ }^{20}$

Memperhatikan dan menganalisis pada contoh kasus Dewi Anita dan Bayu Aji, pada dasarnya menjadi tanggung jawab dari BFS sebagai lembaga penyelenggara, hal ini sesuai dengan ketentuan Pasal 29 POJK No 1/POJK.07/2013 yang menyatakan bahwa segala kesalahan dan/atau kelalaian yang diakibatkan oleh pengurus, pegawai atau pun pihak ketiga dari pelaku usaha jasa keuangan, maka menjadi tanggung jawab pelaku usaha keuangan atas kesalahan ataupun kelalaian yang mengakibatkan kerugian. Lebih lanjut, berdasarkan Pasal 15 Undang-Undang Nomor 11 Tahun 2008 tentang Informasi dan Transaksi Elektronik (selanjutnya disebut dengan UU ITE) menyatakan bahwa penyelenggara sistem elektronik bertanggung jawab secara andal dan aman serta sistem operasional dari sistem elektronik. Namun, penyelenggara tidak perlu bertanggungjawab apabila kesalahan dari sistem elektronik tersebut terjadi akibat adanya keadaan memaksa ataupun kesalahan dari pihak pengguna sistem elektronik. ${ }^{21}$ Melihat kasus Dewi Anita dan Bayu Aji, kesalahan sistem sepenuhnya ada pada pihak BFS ataupun yang bisa mengoperasikan sistem elektronik.

Tidak hanya itu, masalah ini pun bertentangan dengan Pasal 26 ayat 2 UU ITE yang menyatakan informasi transaksi elektronik hak pribadi juga termasuk bagian dari perlindungan data pribadi, di mana salah satu hak pribadi yang dimaksud adalah hak bebas dari segala gangguan dan layak menikmati kehidupan pribadi. Dalam hal ini Dewi Anita dan Bayu Aji akibat kelalaian dari pihak BFS mengakibatkan Dewi Anita dan Bayu Aji ditagih secara terus menerus baik di dalam jam kerja maupun di luar jam kerja. Pada dasarnya belum ada ketentuan mengikat atau sanksi bagi para pelaku usaha yang telah menggunakan kata syariah diujung usahanya dan tidak menerapkan prinsip syariah. Menurut Fatwa DSN-MUI No 117/DSN-MUI/II/2018 apabila terdapat sengketa di antara para pihak, maka yang dapat dilakukan oleh para pihak adalah melalui musyawarah mufakat untuk menyelesaikan sengketa tersebut. Namun, apabila musyawarah tidak menemukan jalan tengah, maka penyelesaian sengketa dapat dilalui melalui lembaga penyelesaian sengketa berdasarkan syariah sesuai dengan peraturan perundang-undangan. Maka dari itu, prosedur yang dapat dilakukan oleh para konsumen yang dirugikan akibat tindakan pelaku usaha adalah melakukan pengaduan langsung kepada Lembaga Otoritas Jasa Keuangan, mengajukan gugatan ke Lembaga Badan Penyelesaian Sengketa Konsumen (BPSK), ${ }^{22}$ ataupun dapat menggugat dengan gugatan perdata berdasarkan perbuatan melawan hukum yang diatur dalam Pasal 1365 Kitab Undang-Undang Hukum Perdata yang menyatakan bahwa setiap perbuatan melanggar hukum dan membawa

\footnotetext{
${ }^{20}$ POJK Nomor 1/POJK.07/2013 tentang Perlindungan Konsumen Sektor Jasa Keuangan

${ }^{21}$ Pasal 15 Undang-Undang Nomor 11 Tahun 2008 tentang informasi dan Transaksi Elektronik

${ }^{22}$ Hariyani, I. Perlindungan Hukum dan Penyelesaian Sengketa Bisnis Jasa PM Tekfin, 2019, Jurnal Legilasi Indonesia, Vol 14 No 3, Hlm 345
} 
kerugian, maka yang menimbulkan kerugian tersebut haruslah bertanggung jawab akan tindakannya, mengajukan tuntutan pidana ke berdasarkan UU ITE ataupun peraturan perundang-undangan yang lain.

\section{KESIMPULAN}

Berdasarkan penjelasan yang telah dijabarkan diatas, maka penulis dapat menarik kesimpulan sebagai berikut:

1. P2P Lending syariah yang merupakan pinjaman dengan penerima pinjaman dalam rangka melakukan perjanjian pinjam meminjam dalam mata uang rupiah secara langsung melalui sistem elektronik dengan menggunakan jaringan internet. Perbuatan hukum ini wajib mengikuti aturan prinsip syariah yang telah ditentukan oleh Fatwa MUI, di mana salah satunya wajib berdasarkan prinsip syariah yaitu akad al-ba'i, ijarah, mudharabah, musyarakah, wakalah bi al ujrah, dan qardh. Tidak hanya itu, P2P Lending syariah inipun dalam pelaksanaan wajib menghindari adanya gharar, riba, tadlis, dharar, dan maysir. berdasarkan Fatwa DSN-MUI Nomor 117/DSN-MUI/II/2018 model layanan pembiayaan berbasis syariah ini terbagi menjadi 6, yaitu Pembiayaan pengadaan barang pesanan pihak ketiga, pembiayaan anjak piutang, Pembiayaan pengadaan barang untuk pelaku usaha yang berjualan secara online dengan pembayaran melalui penyelenggara payment gateway, Pembiayaan pengadaan barang untuk pelaku usaha yang berjualan secara online, pembiayaan berbasis komunitas, dan Pembiayaan untuk Pegawai. Dari 149 P2P Lending yang terdaftar di OJK hanya ada 11 P2P Lending Syariah di Indonesia Untuk P2P Lending Syariah yang terdaftar di OJK transparansi dari sistem keuangannya pun jelas sehingga dapat terpantau oleh OJK. Memang pada dasarnya ke 11 P2P Lending syariah tersebut sudah melaksanakan akad-akad yang ada di FATWA DSN MUI Nomor 117/DSN-MUI/II/2018, namun tidak menutup kemungkinan tidak terjadi kesalahan. Berdasarkan Data yang dimiliki oleh OJK dari Juli 2018 hingga Desember 2020 sudah tercatat 35.250 perusahaan P2P Lending baik konvensional maupun syariah yang ilegal.

2. Mengingat banyaknya kasus yang ada di P2P Lending syariah mengakibatkan OJK dituntut untuk dapat menindak dan mengatasi kasus-kasus dalam pelaksanaan P2P Lending syariah. Dalam kasus Dewi Anita dan Bayu Aji yang dirugikan akibat pelaksanaan dari BFS, para pihak dapat menyelesaikan sengketa tersebut melalui musyawarah ataupun mufakat, hal ini berdasarkan amanat dari Fatwa DSN-MUI No 117/DSN-MUI/II/2018, namun apabila musyawarah tidak menemukan jalan tengah, maka para pihak dapat membawa sengketa ini ke jalur hukum. Dalam Fatwa DSNMUI No 117/DSN-MUI/II/2018 tidak mencantumkan sanksi yang dapat diberikan kepada penyelenggara yang tidak menerapkan prinsip syariah, sehingga para pihak 
dapat mengajukan gugatan perdata maupun pidana. Dalam kasus ini para pihak dapat menggugat melalui gugatan perdata berdasarkan perbuatan melawan hukum yang diatur dalam Pasal 1365 Kitab Undang-Undang Hukum Perdata, pidana dikarenakan penyelenggara telah melanggar Pasal 15 dan Pasal 26 ayat 2 UU ITE, ataupun mengajukan aduan kepada Otoritas Jasa Keuangan akibat dari penyelenggara telah melanggar Pasal 25 ayat 3 dan Pasal 47 ayat 1 POJK Nomor 77/POJK.01/2016 dalam hal ini sanksi yang diberikan ialah peringatan tertulis, denda, pembatasan kegiatan usaha, dan pencabutan usaha.

\section{DAFTAR PUSTAKA}

\section{Buku :}

Ash-Shawi dan Muhammad Shalah Muhammad. Problematika Investasi Pada Bank Slam Solusi Ekonomi. Jakarta: Migunani, 2008.

Azzam Abdul dan Aziz Muhammad. Fiqh Muamalat System Transaksi Dalam Islam. Jakarta: AMZAH, 2010.

Johannes Gunawan. "Fungsi Lembaga Pertanggungjawaban Produk Dalam Upaya Perlindungan Konsumen Di Indonesia,” 2003.

Peter Mahmud Marzuki. Penelitian Hukum. Jakarta: Kencana Prenada Media Group, 2005.

Sjahdeini, Sutan Remy. Perbankan Syariah Produk-Produk Dan Aspek-Aspek Hukumnya. Jakarta: Kencana Prenamedia Group, 2014.

Soerjono Soekanto dan Sri Mamudji. Penelitian Hukum Normatif: Suatu Tinjauan Singkat. Jakarta: PT Raja Grafindo Persada, 2003.

\section{Jurnal :}

Dita Tania dan Sri Bakti Yunari. "Perlindungan Hukum Terhadap Konsumen Financial Technology Yang Berbasis Peer to Peer Lending Di Indonesia.” Jurnal Hukum Adigama 3, no. 1 (2020): 15.

Dodi Yarli. "Analisis Akad Tijarah Pada Transaksi Fintech Syariah Dengan Pendekatan Maqhasid." Jurnal YUDISI 9, no. 2 (2018): 2.

Fuqoha, Fuqoha, Indrianti Azhar Firdausi, and Arga Eka Sanjaya. "Perlindungan Hukum Terhadap Intervensi Pemberitaan Dalam Kerangka Kemerdekaan Pers Nasional.” Ajudikasi : Jurnal Ilmu Hukum 3, no. 1 (2019): 75. https://doi.org/10.30656/ajudikasi.v3i1.1436.

Hariyani, I. 2019. Perlindungan Hukum dan Penyelesaian Sengketa Bisnis Jasa PM Tekfin. Jurnal Legilasi Indonesia, Vol 14 No 3

Heri Suhendra, Ayon Diniyanto. 2020. Pengawasan Dan Regulasi Terhadap Financial Technology Lending Syariah. El-Iqtishady. Vol 2 No 2 
Nurhasanah dan ndra Rahmatullah. 2020. "The Legal Protection of Sharia Financial Technology in Indonesia (Analysis of Regulation, Structure and Law Enforcement)", nternational Journal of Advanced Science and Technology. Vol. 29, 3.

Purba, M. Hadyan Yunhas. "Penguatan Perlindungan Konsumen Dalam Industri Peer to Peer Lending Di Indonesia.” Kanun Jurnal Ilmu Hukum 22, no. 3 (2020): 4.

Raden Ani Eko Wahyuni. 2019. Perkembangan Ekonomi Islam Di Indonesia Melalui Penyelenggaraan Fintech Syariah. Mahkamah: Jurnal Kajian Hukum Islam, Vol 4 No 2

Rahmatullah dan Nurhasanah dan Indra. "The Legal Protection of Sharia Financial Technology in Indonesia (Analysis of Regulation, Structure and Law Enforcement)." International Journal of Advanced Science and Technology 29, no. 3 (2020): 3089.

Rokilah, Rokilah. "The Role of the Regulations in Indonesia State System." Ajudikasi : Jurnal Ilmu Hukum 4, no. 1 (2020): 29-38. https://doi.org/10.30656/ajudikasi.v4i1.2216.

\section{PERATURAN PERUNDANG-UNDANGAN}

Kitab Undang-Undang Hukum Pidana

Kitab Undang-Undang Hukum Perdata

Undang-Undang Nomor 11 Tahun 2008 Tentang Informasi dan Transaksi Elektronik

POJK Nomor 1/POJK.07/2013 tentang Perlindungan Konsumen Sektor Jasa Keuangan

POJK Nomor 77/POJK.01/2016 tentang Layanan Pinjam Meminjam Uang Berbasis Teknologi informasi

Fatwa DSN-MUI Nomor 117/DSN-MUI/II/2018 tentang Layanan Pembiayaan Berbasis Teknologi informasi Berdasarkan Prinsip Syariah

\section{INTERNET}

Dewi Anita, Sistem Penagihan Pinjol Berkah Fintek Syariah Bermasalah, diakses dari https://mediakonsumen.com/2020/12/19/surat-pembaca/sistem-penagihan-pinjolberkahfintek-syariah-bfs-bermasalah

Sovia Hasanah, Kedudukan fatwa MUI dalam Hukum Nasional, https://www.hukumonline.com/klinik/detail/ulasan/lt5837dfc66ac2d/kedudukan-fatwamui-dalam-hukum-Indonesia 
AJUDIKASI : Jurnal Ilmu Hukum, Volume 5 Nomor 1, Juni 2021. Hlm 17-34

P-ISSN 2613-9995 \& E-ISSN 2614-0179 